\title{
PENGARUH PENAMBAHAN GARAM NATRIUM DALAM PROSES PENGENDAPAN LIMBAH PENGOLAHAN GAMBIR TERHADAP RENDEMEN TANIN
}

\section{Influence of Natrium Addition in Precipitation Process of Gambier Treatment Wastewater to Tannin Yield}

\author{
Hendri Muchtar \\ Balai Riset dan Standardisasi Industri Padang \\ JI. Raya LIK Ulu Gadut No. 23 Telp. (0751) 72201 Fax.(0751) 71320 Padang 25164 \\ e-mail: hendrimuchtar@yahoo.co.id
}

Diterima: 14 Februari 2013, Disetujui: 30 April 2013

\begin{abstract}
ABSTRAK
Air limbah industri pengolahan gambir yang mengandung senyawa tanin saat ini belum dimanfaatkan secara optimum. Limbah cair ini dapat digunakan sebagai sumber warna alami atau tanin, namun tidak tahan dalam penyimpanan karena sering ditumbuhi jamur, sehingga dalam bentuk padatan/tepung tanin akan lebih menguntungkan. Untuk mendapatkan endapan tanin dilakukan penelitian pengaruh penambahan bahan pengendap terhadap pembentukan tanin dari limbah proses pengolahan gambir. Penelitian ini bertujuan untuk mendapatkan rendemen tanin yang optimal melalui proses pengendapan. Bahan pengendap yang digunakan adalah garam $\mathrm{NaCl}$ teknis, garam dapur, sedangkan untuk pengatur $\mathrm{pH}$ digunakan natrium bikarbonat dan larutan jenuh air kapur.Tahap pengendapan $\mathrm{pH}$ larutan diatur dengan menambahkan $\mathrm{NaHCO}_{3}$ atau air kapur jenuh sedemikian rupa sampai $\mathrm{pH}$ 8. Penambahan garam $\mathrm{NaCl}$ atau garam dapur pada limbah cair industrin pengolahan gambir dengan konsentrasi antara $50 \mathrm{~g} / \mathrm{L}, 100 \mathrm{~g} / \mathrm{L}, 150 \mathrm{~g} / \mathrm{L}, 200 \mathrm{~g} / \mathrm{L}, 250 \mathrm{~g} / \mathrm{L}, 300 \mathrm{~g} / \mathrm{L}, 350 \mathrm{~g} / \mathrm{L}, 400 \mathrm{~g} / \mathrm{L}$ pada 200 $\mathrm{ml}$ limbah cair pengolahan gambir. Dari hasil penelitian diperoleh endapan yang optimal adalah dengan penambahan $\mathrm{NaCl}$ teknis dengan konsentrasi $300 \mathrm{~g} / \mathrm{L}$ dengan menggunakan pengatur $\mathrm{pH}$ Natrium bikarbonat dengan rendemen sebesar 30,05\%. Penambahan $\mathrm{NaCl}$ dengan konsentrasi diatas $300 \mathrm{~g} / \mathrm{L}$ memberikan hasil yang tidak jauh berbeda. Zat warna tanin dari limbah cair pengolahan gambir berupa tepung soga berwarna cokelat.
\end{abstract}

\section{Kata Kunci: Zat warna, tanin, gambir}

\begin{abstract}
Wastewater from gambier industry which contains tannin has not been utilized optimally yet. The wastewater does not hold up in storage because is often overgrown with fungus, so that in the solid / powdery tannins will be more profitable. To get the tannins precipitate, it had been done research about the effect of settling material to the formation of gambier dye from waste gambier industry. This study aimed to obtain optimum yield of tannins through the precipitation process. Settling material which were used technically $\mathrm{NaCl}$ salt and table salt, while for $\mathrm{pH}$ regulator used sodium bicarbonate and saturated solution of lime. Phase of precipitation was done by adding $\mathrm{NaHCO}_{3}$ or lime water saturated in such a manner until $\mathrm{pH}$ 8. The addition of $\mathrm{NaCl}$ salt or table salt with concentration $50 \mathrm{~g} / \mathrm{L}, 100 \mathrm{~g} / \mathrm{L}, 150 \mathrm{~g} / \mathrm{L}, 200 \mathrm{~g} / \mathrm{L}, 250 \mathrm{~g} / \mathrm{L}, 300 \mathrm{~g} / \mathrm{L}, 350 \mathrm{~g} / \mathrm{L}, 400 \mathrm{~g} / \mathrm{L}$ in $200 \mathrm{ml}$ of gambier industry liquid waste. The research result was obtained that the optimum precipitate by the addition of $\mathrm{NaCl}$ with concentrations $300 \mathrm{~g} / \mathrm{L}$ and the use of sodium bicarbonate as a $\mathrm{pH}$ regulator gave $30.05 \%$ yield. The addition of $\mathrm{NaCl}$ with concentrations above $300 \mathrm{~g} / \mathrm{L}$ gave results which were not much different. Tannin dyes from wastewater of gambier treatment were in the form of brown colour flour.
\end{abstract}

\section{Keywords: Dyes, tannin, gambier}




\section{PENDAHULUAN}

Gambir adalah ekstrak daun dan ranting tanaman Uncaria Gambir (Hunter) Roxb yang dikeringkan dan dicetak dalam berbagai bentuk. Kandungan kimia utama gambir yang dilaporkan berdasarkan hasil penelitian Thorpe dan Whiteley (1921) serta Burkill (1935) adalah katechin 7-33\%, produk kondensasi dalam bentuk asam katechu tannat atau tanin (20-50\%), pyrokatecol $20-30 \%$, gambir fluoresensi 1 $3 \%$, katechin merah $3-5 \%$, quersetin $2-4 \%$, fix oil $1-2 \%$, lilin $1-2 \%$, dan kandungan alkaloid dalam jumlah kecil.

Katechin dan tanin merupakan kandungan utama dari gambir yang termasuk senyawa kompleks dari golongan polifenol dengan struktur flavonoid, dimana asam katechu tannat $\left(\mathrm{C}_{15} \mathrm{H}_{12} \mathrm{O}_{5}\right)$ merupakan anhidrat dari katechin $\left(\mathrm{C}_{15} \mathrm{H}_{14} \mathrm{O}_{6}\right)$. Katechin biasa disebut asam katekuat atau asam katekiat dengan rumus (2R-trans) -2- (3,4dihydroxyphenyl), 3,4-dihydro-2H-1 benzopyran, 3,5,7 triol) atau 3,5,7,3',4'pentadihidroksiflavan (Parker et al, 1983; Day and Underwood,1991).

Gambir merupakan komoditi ekspor andalan Sumatera Barat dengan daerah penghasil utama adalah Kabupaten Pesisir Selatan dan Kabupaten 50 kota. Sumatera Barat saat ini merupakan pemasok gambir terbesar $(80 \%)$ di Indonesia dan dunia, dimana gambir diekspor ke berbagai negara seperti India, Singapura, Jepang dan negara lainnya. Kegunaan gambir secara tradisional sebagai pelengkap makan sirih dan obatobatan seperti untuk obat anti diare, disentri, obat kumur-kumur, sariawan dan lain-lain. Dalam dunia industri, gambir sering digunakan sebagai bahan penyamak kulit dan pewarna tekstil (Nazir, 2000; Bakhtiar, 2005).

Dalam proses pengolahan gambir baik yang menghasilkan gambir asalan dan gambir yang diolah lagi seperti gambir murni maupun produksi cube black gambir akan dihasilkan limbah cair yang mengandung senyawa tanin yang relatif tinggi. Menurut Yusmeiarti dkk (2008), limbah cair industri pengolahan gambir ini dapat digunakan sebagai sumber zat warna soga alami yang digunakan untuk pencelupan kain. Namun secara ekonomis limbah cair ini belum digunakan secara optimal karena tidak dapat bertahan lama disebabkan ditumbuhi jamur, disamping itu sulit dalam hal pengemasan dan transportasi, sehingga akan lebih mudah dikemas jika dalam bentuk padat atau berupa tepung.

Tanin adalah senyawa fenolik yang dapat bereaksi dengan protein dan dapat membentuk senyawa kompleks yang tidak larut. Tanin tidak dapat larut dalam pelarut organik seperti misalnya; eter, kloroform, benzena, tetapi sedikit larut dalam etil asetat. Tanin larut dalam air dan alkohol dan akan membentuk larutan koloidal.

Dalam larutan basa, tanin mudah larut membentuk garam tannat. Dalam industri, tanin antara lain digunakan sebagai bahan pembuat tinta dan obat-obatan (Gustri dan Hendri, 2000)

Tanin pada umumnya diperoleh dari batang kayu, kulit kayu, buah, akar maupun daun tumbuh-tumbuhan, Beberapa sifat tanin antara lain berwarna kekuningan sampai coklat cerah. Umumnya berupa serbuk atau kepingan. Berikut contoh reaksi pembentukan asam gallat (tanin kondensasi) sebagai berikut;

$$
\begin{aligned}
& \mathrm{C}_{13} \mathrm{H}_{16} \mathrm{O}_{10}+\mathrm{H}_{2} \mathrm{O} \rightarrow \mathrm{C}_{6} \mathrm{H}_{6}(\mathrm{OH})_{3} \mathrm{COOH}+\mathrm{C}_{6} \mathrm{H}_{12} \mathrm{O}_{6} \\
& \text { Galatonin Air Asam gallat glukosa }
\end{aligned}
$$

Asam gallat yang terbentuk kemudian dinetralkan selanjutnya diendapkan dengan bantuan $\mathrm{NaCl}$ sehingga terbentuk endapan Na-gallat atau endapan soga (O'Flaherty dalam Mumpuni, 2005).

Penggunaan $\mathrm{NaCl}$ dalam proses pengendapan dapat bersifat sebagai koagulan. Pada penelitian ini juga digunakan garam dapur yang mempuyai kandungan $\mathrm{NaCl}$ sekitar $94 \%$, sedangkan $\mathrm{NaCl}$ teknis mengandung kadar $\mathrm{NaCl}$ besar dari $99 \%$.

Keberhasilan proses ekstraksi pada pembuatan soga sangat dipengaruhi oleh berbagai macam faktor, antara lain; suhu ekstraksi, perbandingan antara pelarut dengan bahan yang diekstraksi, waktu ekstraksi dan ukuran bahan yang diekstraksi.

Kandungan senyawa tanin yang relatif tinggi pada limbah proses pengolahan gambir tersebut mempunyai potensi yang besar untuk digunakan sebagai bahan 
pewarna dalam bentuk serbuk sebagai pewarna tekstil maupun penggunaan lainnya. Zat warna alam adalah zat warna yang berasal dari bahan alam tumbuhan dan hewan. Zat warna alam dari bagian tumbuhan akar batang kayu, kulit, daun, bunga dan getah.

Berdasarkan struktur dari zat warna alami dapat digolongkan atas zat warna alam inti porfirin seperti klorofil, haemoglobin, mioglobin. Golongan flavonoid seperti kaemferol dan quersetin. Golongan antosianin seperti pelorgamdin, sianidin, delfidin, peomdin, petunidin dan malvidin. Golongan proantosianin seperti katechin, epikatekin, antisianidin. Sedangkan zat warna sintetis biasanya terbuat dari hidrokarbon-hidrokarbon aromatik. Zat-zat penting dalam gambir adalah katechin yaitu golongan senyawa ester dari aromatik asam oxycarbon sejenis flavonol dan anthocyanin merupakan zat warna.

Dalam dunia industri tekstil warna gambir yang timbul oleh garam diazonium dapat bermacam-macam tergantung pada garam diazonya yang dipakai untuk membangkitkannya dan bila dilihat warna yang timbul umumnya mengarah antara warna kuning cokelat sampai hitam cokelat, zat warna gambir termasuk zat warna soga alam (Venkataraman, 1969, Luftinor, 1997).

Pemakaian zat warna alam dibeberapa negara masih diyakini lebih aman dari pada zat warna sintetis. Melihat potensi limbah cair pengolahan gambir yang cukup besar dan limbah ini tidak tahan dalam penyimpanan maka peluang untuk menghasilkan zat warna alam dari limbah cair lebih terbuka. Oleh sebab itu perlu kiranya dilakukan penelitian pengaruh beberapa jenis garam natrium dan bahan pengatur $\mathrm{pH}$ untuk mendapatkan hasil yang optimum.

\section{METODOLOGIPENELITIAN}

\section{Bahan}

Bahan yang digunakan dalam penelitian ini adalah; limbah cair dari proses pengolahan gambir, garam dapur, $\mathrm{NaCl}$ teknis, $\mathrm{NaHCO}_{3}, \mathrm{CaCO}_{3}$, dan air suling.
Alat

Peralatan penelitian terdiri atas: Neraca analitik, kertas saring, peralatan gelas, pengaduk.

\section{Metoda}

Persiapan contoh limbah proses pengolahan gambir . Limbah diperoleh dari proses pengolahan gambir disaring dengan menggunakan kain saring halus untuk membuang kotoran.

Pengendapan tanin yang terdapat pada limbah cair pengolahan gambir dilakukan dengan menggunakan beberapa bahan pengendap dengan variasi perlakuan yaitu: Jenis bahan pengendap $(A)$ yang terdiri dari Natrium chlorida (A1) dan Garam dapur (A2) serta Bahan Pengatur $\mathrm{pH}(\mathrm{B})$ yang terdiri dari $\mathrm{NaHCO} 3$ (B1) dan Air kapur jenuh (B2).

Dari berbagai jenis bahan pengendap dengan variasi tersebut di atas dilakukan pengendapan pada $\mathrm{pH} 8$.

\section{Cara Kerja}

1. Masukkan limbah cair sebanyak $200 \mathrm{ml}$ ke dalam gelas piala.

2. Ditambahkan air kapur atau $\mathrm{NaHCO}_{3}$ yang telah dijenuhkan dengan air suling terlebih dahulu ke dalam gelas piala tersebut sampai didapat $\mathrm{pH} 8$.

3. Ditambahkan $\mathrm{NaCl}$ atau garam dapur pada masing-masing gelas piala sebanyak masing-masing $20 \mathrm{ml}$. dengan variasi konsentrasi sebagai berikut : 50 $\mathrm{g} / \mathrm{L}, 100 \mathrm{~g} / \mathrm{L}, 150 \mathrm{~g} / \mathrm{l}, 200 \mathrm{~g} / \mathrm{l}, 250 \mathrm{~g} / \mathrm{L}$, $300 \mathrm{~g} / \mathrm{L}, 350 \mathrm{~g} / \mathrm{L}$ dan $400 \mathrm{~g} / \mathrm{L}$. Aduk sampai semua larutan homogen.

4. Biarkan terjadi pengendapan selama 24 jam.

5. Saring endapan yang terbentuk dengan menggunakan kertas saring.

6. Keringkan dan timbang endapan yang terbentuk.

\section{Analisis}

Analisis dilakukan terhadap rendemen endapan tanin dan kadar tanin limbah cair gambir.

\section{HASILDAN PEMBAHASAN}


Dari hasil penelitian yang dilakukan diperoleh hasil sebagai berikut:

\section{Analisis Kadar Tanin Limbah Cair Pengolahan Gambir.}

Analisis kadar tanin dari limbah cair pengolahan gambir diperoleh sebesar $30 \%$. Limbah berbentuk larutan berwarna cokelat kehitaman.

\section{Pengaruh Penambahan Natrium klorida} dengan menggunakan larutan $\mathrm{NaHCO}_{3}$ sebagai pengatur $\mathrm{pH}$ pada limbah gambir.

Pada penambahan $\mathrm{NaCl}$ dengan konsentrasi $50 \mathrm{~g} / \mathrm{L}$ pada $200 \mathrm{ml}$ limbah cair dihasilkan endapan seberat $21,1 \mathrm{mg}$, akan terus meningkat sampai pada penambahan $\mathrm{NaCl}$ dengan konsentrasi $300 \mathrm{~g} / \mathrm{L}$ dengan hasil endapan sebesar $60,1 \mathrm{mg}$. Pada penambahan $350 \mathrm{~g} / \mathrm{L}$ dan $400 \mathrm{~g} / \mathrm{L}$ tidak memberikan hasil yang signifikan seperti halnya pada Gambar 1.

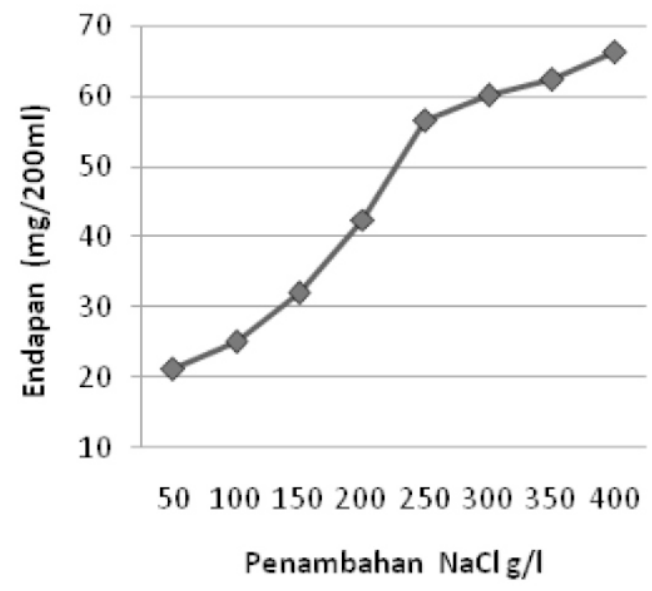

Gamoar 1. Rengarun Konsentrası IvaCl terhadap berat endapan tanin dengan menggunakan pengatur $\mathrm{pH} \mathrm{NaHCO}_{3}$.

Pengaruh penambahan garam dapur dengan menggunakan larutan air kapur jenuh untuk pengatur $\mathrm{pH}$ pada limbah gambir.

Garam dapur adalah garam yang mengandung senyawa $\mathrm{NaCl}$ dalam konsentrasi yang lebih rendah jika dibandingkan dengan senyawa $\mathrm{NaCl}$ teknis.

Penambahan garam dapur ini pada limbah cair pengolahan gambir dan air kapur jenuh sebagai pengatur $\mathrm{pH}$ untuk mendapatkan endapan tanin memberikan hasil yang lebih rendah jika dibandingkan dengan penambahan $\mathrm{NaCl}$ teknis di atas. Hal ini kemungkinan disebabkan kandungan $\mathrm{NaCl}$ pada garam dapur yang lebih rendah jika dibandingkan dengan penggunaan $\mathrm{NaCl}$ teknis. Pada penambahan garam dapur dengan konsentrasi $50 \mathrm{~g} / \mathrm{L}$ dihasilkan endapan sebesar 19,6 mg. Berat endapan meningkat dengan penambahan sampai pada konsentrasi garam dapur $300 \mathrm{~g} / \mathrm{L}$, yaitu sebesar 39,2 mg. Penambahan diatas 300 $\mathrm{g} /$ Lmemberikan hasil yang tidak jauh berbeda. Hal ini dapat dilihat pada Gambar 2, dimana terdapat grafik mendatar pada penambahan konsentrasi garam dapur 300 g/L ke atas.

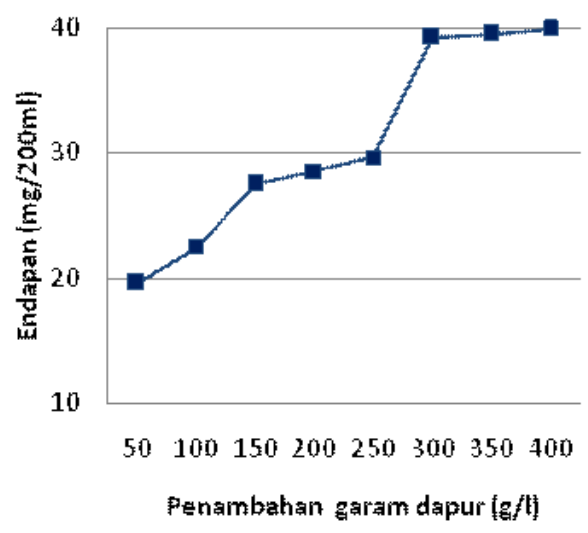

Gambar 2. Pengaruh konsentrasi garam dapur terhadap berat endapan tanin dengan menggunakan air kapur jenuh untuk mengatur $\mathrm{pH}$

\section{Pengaruh penggunaan $\mathrm{NaCl}$ dengan penambahan air kapur sebagai pengatur pH pada limbah gambir.}

Penambahan $\mathrm{NaCl}$ dengan konsentrasi diatas $300 \mathrm{~g} / \mathrm{L}$ memberikan hasil yang tidak jauh berbeda. Penggunaan $\mathrm{NaCl}$ sebagai bahan pengendap dan air kapur sebagai pengatur $\mathrm{pH}$ memberikan hasil relatif rendah jika dibandingkan dengan penggunaan $\mathrm{NaCl}$ dan pengatur $\mathrm{pH} \mathrm{NaHCO}{ }_{3}$ seperti Gambar 1. Penambahan $\mathrm{NaCl}$ dengan konsentrasi 50 $\mathrm{g} / \mathrm{L}$ diperoleh endapan sebesar 10,21 mg. Hasil yang diperoleh jauh lebih rendah jika dibandingkan dengan penggunaan bahan pengendap $\mathrm{NaCl}$ dengan konsentrasi yang 
sama. Berat endapan meningkat dengan penambahan sampai pada konsentrasi garam dapur $300 \mathrm{~g} / \mathrm{L}$, yaitu sebesar $37,0 \mathrm{mg}$.

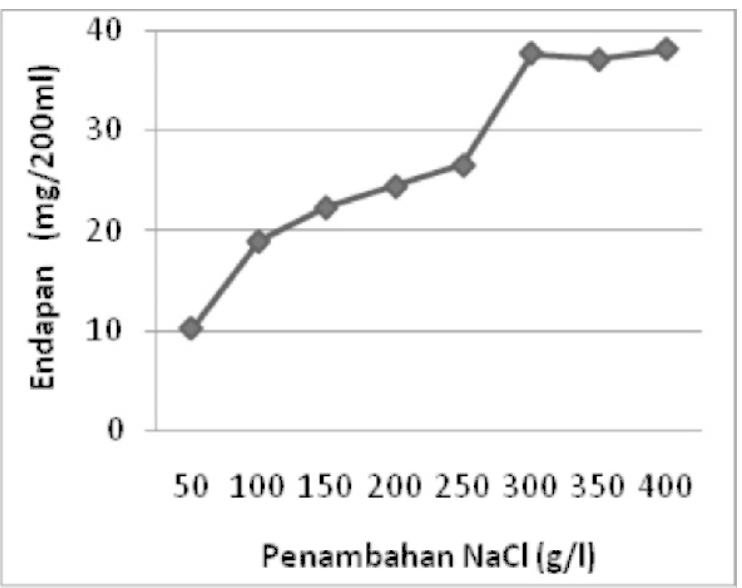

Gambar 3. Pengaruh konsentrasi $\mathrm{NaCl}$ terhadap berat endapan tanin dengan menggunakan pengatur $\mathrm{pH}$ air kapur

\section{Pengaruh garam dapur dengan bahan pengatur $\mathrm{pH}$ menggunakan larutan $\mathrm{NaHCO}_{3}$ pada limbah gambir.}

Penambahan garam dapur dan larutan $\mathrm{NaHCO}_{3}$ pada limbah cair pengolahan gambir memberikan hasil yang jauh lebih rendah dibandingkan dengan penggunaan bahan pengendap dan pengatur $\mathrm{pH}$ seperti pada Gambar 1, 2 dan 3 .

Pada penambahan $\mathrm{NaCl} 50 \mathrm{~g} / \mathrm{L}$ akan dihasilkan endapan seberat 21,1 mg, akan terus meningkat dengan peningkatan konsentrasi sampai pada penambahan 300 $\mathrm{g} / \mathrm{L}$ dengan hasil endapan sebesar 23,2 mg. Pada penambahan $350 \mathrm{~g} / \mathrm{L}$ dan $400 \mathrm{~g} / \mathrm{L}$ tidak memberikan hasil yang berbeda secara signifikan. Hubungan berat endapan dengan konsentrasi garam dapur menggunakan $\mathrm{NaHCO}_{3}$ sebagai pengatur $\mathrm{pH}$ dapat dilihat pada Gambar 4.

Dari Gambar 4 terlihat bahwa penambahan $\mathrm{NaCl}$ sebagai zat pengendap dan garam dapur memberikan grafik yang menanjak sampai pada penambahan konsentrasi $300 \mathrm{~g} / \mathrm{L}$. Penambahan diatas $300 \mathrm{~g} / \mathrm{L}$ kurva mulai mendatar.

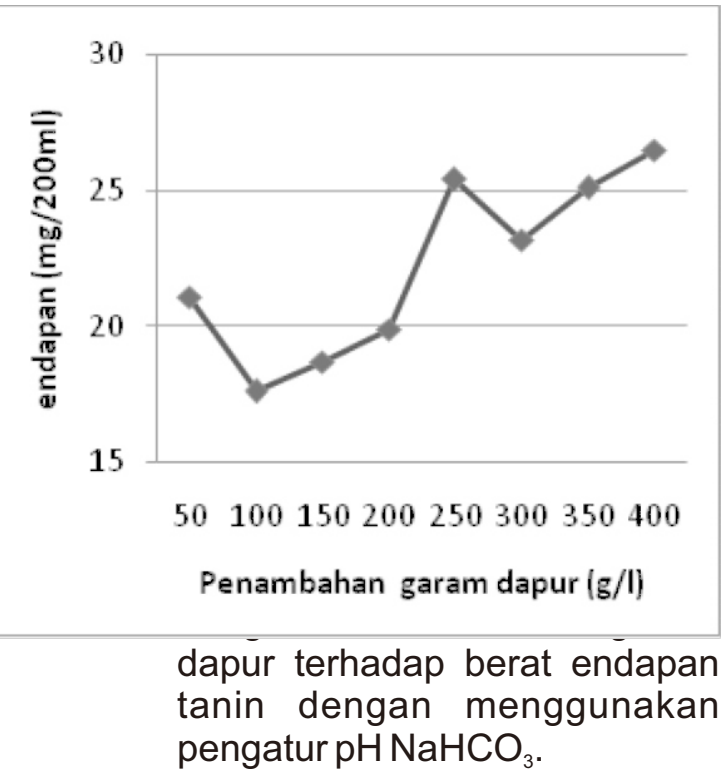

\section{Rendemen}

Jenis bahan pengendap dan senyawa pengatur $\mathrm{pH}$ berpengaruh terhadap rendemen dari endapan tanin yang terbentuk. Kombinasi bahan pengendap dan pengatur $\mathrm{pH}$ yang digunakan meliputi $\mathrm{NaCl} / \mathrm{NaHCO}_{3}$, garam dapur/air kapur, $\mathrm{NaCl} / a i r$ kapur serta garam dapur/ $\mathrm{NaHCO}_{3}$ memberikan hasil yang berbeda. Rendemen yang terbanyak dihasilkan oleh $\mathrm{NaCl} / \mathrm{NaHCO}_{3}$ dengan rendemen tertinggi pada penambahan $\mathrm{NaCl} 300 \mathrm{~g} / \mathrm{L}$ adalah sebesar 30,05\% . Hal ini dapat dilihat pada Gambar 5.

Penambahan $\mathrm{NaCl}$ berfungsi sebagai koagulan yang berpengaruh terhadap endapan zat warna yang terbentuk. Karena ion $\mathrm{Cl}^{-}$yang terdapat dalam larutan mempunyai daya adsopsi yang lebih kuat sehingga pada permukaan partikel terdapat lapisan ion khlorida bermuatan negatif. Ion $\mathrm{Cl}^{-}$akan membentuk lapisan primer selanjutnya menarik ion-ion $\mathrm{Na}^{+}$membentuk lapisan sekunder. Lapisan tersebut menyebabkan partikel-partikel bergabung membentuk partikel yang lebih besar yang mengendap pada dasar wadah, sehingga makin banyak penambahan $\mathrm{NaCl}$ maka makin banyak endapan yang terbentuk seperti pada Gambar 5 sampai batas optimumnya (Hendri, 2000) 


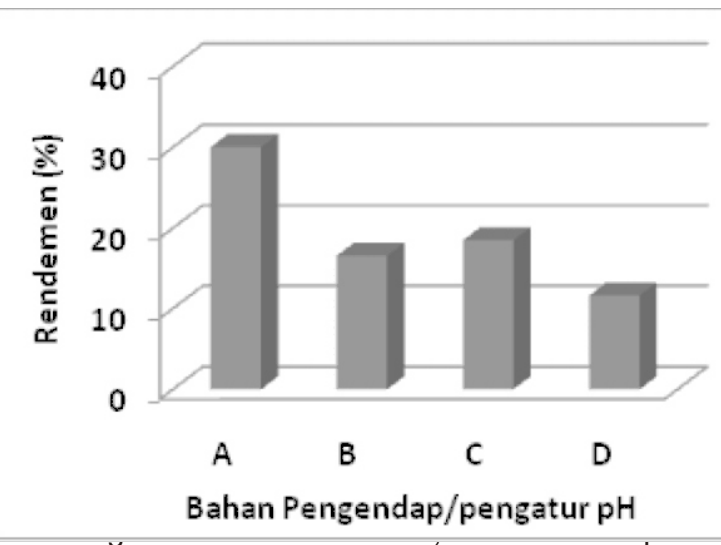

kapur, $\breve{C}=\mathrm{NaCl} /$ air kapur, dan $\mathrm{D}=$ Garam dapur/NaHCO3.

Gambar 5. Pengaruh penambahan jenis garam Natrium terhadap rendemen tanin.

Penambahan $\mathrm{NaCl}$ memberikan hasil rendemen tanin yang lebih banyak jika dibandingkan dengan penggunaan garam dapur. Garam dapur adalah sejenis mineral yang berbentuk kristal putih mengandung senyawa $\mathrm{NaCl}$ dan senyawa lainnya yang terikut bersamanya, sehingga kandungan $\mathrm{NaCl}$ lebih rendah jika dibandingkan dengan penggunaan $\mathrm{NaCl}$ teknis, begitu juga dengan rendemen tanin yang diperoleh. Disamping penggunaan $\mathrm{NaCl}$ dan pengatur $\mathrm{pH} \mathrm{NaHCO} 3$ karena adanya dua ion logam $\mathrm{Na}+$ dari $\mathrm{NaCl}$ dan $\mathrm{NaHCO} 3$ akan memberi pengaruh terhadap proses pengendapan.

\section{KESIMPULAN DAN SARAN}

\section{Kesimpulan}

Dari hasil penelitian diperoleh kesimpulan bahwa :

1. Penggunaan bahan pengendap $\mathrm{NaCl}$ teknis dan garam dapur serta $\mathrm{NaHCO}_{3}$ dan larutan jenuh air kapur sebagai pengatur $\mathrm{pH}$ untuk mengendapkan senyawa tanin yang terdapat dalam limbah cair proses pengolahan gambir akan meningkat dengan bertambahnya konsentrasi senyawa yang ditambahkan sampai konsentrasi $\mathrm{NaCl}$ mencapai 300 $\mathrm{g} / \mathrm{l}$, penambahan diatas konsentrasi tersebut memberikan hasil yang tidak jauh berbeda.

2. Hasil terbaik yang diperoleh dari penambahan bahan pengendap $\mathrm{NaCl}$ dan garam dapur serta pengatur $\mathrm{pH}$ $\mathrm{NaHCO}_{3}$ dan air kapur adalah penggunaan $\mathrm{NaCl}$ teknis dengan $\mathrm{NaHCO}_{3}$ sebagai pengatur keasaman $(\mathrm{pH})$ larutan dengan rendemen $30,05 \%$.

\section{Saran}

Disarankan bahwa walaupun penggunaan garam dapur sebagai zat pengendap dan air kapur untuk pengatur $\mathrm{pH}$ memberikan hasil yang relatif rendah, jika dibandingkan dengan pengendap lain namun lebih mudah diperoleh dengan harga yang lebih murah.

\section{DAFTAR PUSTAKA}

Bakhtiar, A. 2005. Potensi Senyawa Bahan Alam Flavanoid Sebagai Obat dan Kosmetik, Pidato Pengukuhan Sebagai Guru Besar Tetap dalam IImu Farmasi, Disampaikan pada Rapat Senat luar Biasa Universitas Andalas, Padang, 4 Pebruari 2005.

Burkill, I. H.1935. Dictionery of the Economic Product of Malay Peninsula, Vol II, Goverment of Malaysia and Singapore, Kuala Lumpur,pp 2196-2204.

Day, R. A dan A. L. Undeswood. 1991. Analisa Kimia Kuantitatif, Diterjemahkan Oleh R. Soendoro, Erlangga, Jakarta.

Gustri Y., Hendri, M. 2000. Pengaruh Waktu Pemanasan Terhadap Cube Black Gambir dan Aplikasi Sebagai Penyamak Kulit, Jurnal Riset Industri dan Perdagangan, Volume 3, No.2, Desember.

Hendri M., Yusmearti, 2000. Laporan Penelitian Pemanfaatan Limbah Cair Pemurnian Gambir sebagai bahan pewarna, Balai Litbang Industri Padang.

Luftinor, S. 1997. Penggunaan Zat Warna dari Tanaman Gambir Untuk Pewarnaan Tekstil, Dinamika Penelitian BIPA vol 8 No.13.

Mumpuni, A. 2005. Pengaruh Waktu Ekstraksi dan Jumlah Solven Terhadap 
Rendemen Zat Warna Soga Pada Ektraksi Kulit Batang Mangga, Majalah IImiah Kopertis Wilayah VI Vol XV No.23 Tahun 2005.

Nazir, N. 2000. Gambir, Budidaya Pengolahan dan Prospek Diversifikasinya, Penerbit Yayasan Hasil Hutan non Kayu, Padang.

Parker, S.P., Weil, J., Richman, B., Fox, E.J., et al. 1983. Encyclopedia of Chemistry. Fifth Edition.

Thorphe.JF, and Whiteley, MA. 1921. Thorpe's Dictionery of Applied Chemistry.

Venkataraman, K. 1969. The Chemistry of Synthethic Dyes, Academic Press Inc.,
New York, Second Ed.

Yusmeiarti, Hendri, M. 2000. Laporan Penelitian Pengembangan Teknologi Pemurnian Gambir, Balai Litbang Industri Padang.

Yusmeiarti, Failisnur, Hermianti, W., Marjali, Syafruddin, D., dan Yurnita. 2008. Penelitian dalam penyimpanan limbah cair pengolahan gambir sebagai pewarna tekstil. Komunikasi N0. 241. Baristand Padang 